2004

\title{
Impacts of naturally-occurring soil fungi on seeds of meadow plants
}

Post-print/Accepted manuscript

Michelle Schafer

Peter M. Kotanen

Schafer, M. \& Kotanen, P.M. Plant Ecology (2004) 175: 19. doi:10.1023/B:VEGE.0000048096.00772.23

The final publication is available at Springer via http://dx.doi.org/10.1023/B:VEGE.0000048096.00772.23

\section{HOW TO CITE TSPACE ITEMS}

Always cite the published version, so the author(s) will receive recognition through services that track citation counts, e.g. Scopus. If you need to cite the page number of the TSpace version (original manuscript or accepted manuscript) because you cannot access the published version, then cite the TSpace version in addition to the published version using the permanent URI (handle) found on the record page. 


\title{
Impacts of naturally-occurring soil fungi on seeds of meadow plants
}

\author{
Michelle Schafer and Peter M. Kotanen* \\ Department of Botany, University of Toronto at Mississauga, 3359 Mississauga Road \\ North, Mississauga, Ontario, L5L 1C6 CANADA; \\ *Author for correspondence (e-mail: pkotanen@credit.erin.utoronto.ca)
}


Key words: Grasses, Old fields, Pathogens, Plant disease, Seed banks, Soil fungi

\begin{abstract}
Although soil fungi may represent an ecologically important cause of mortality of buried seeds, few studies have provided direct evidence of the pathogenicity of fungi colonizing seeds in natural habitats. In response, we conducted a series of experiments to investigate the impacts of soil fungi from a range of habitats on seeds of meadow plants. We compared the survival of seeds of four grasses in five habitats, and isolated fungi from these seeds. We then tested the pathogenicity of selected isolates against two standard sets of plant species: the original four grasses and a broad range of old field species. We found that the soil community contained a large variety of seed-colonizing fungi. Some, but not all, examples of these fungi caused seed mortality; others may be harmless commensals. Some of these isolates negatively affected a broad range of plant species, but others had a more restricted host range; as a result, pathogenicity varied depending upon the particular plant-fungus combination. Few between-habitat differences in seed survival were detected. Our results demonstrate that fungal seed pathogens are common, ubiquitous, and potentially lethal, but that their effects depend on the particular combination of fungus and plant species considered.
\end{abstract}




\section{Introduction}

Seed banks play a prominent role in the ecology of many plant species (Roberts 1981, Thompson 1987, Leck et al. 1989, Baskin and Baskin 1998, Thompson et al. 1997). It is believed that a large fraction of mortality frequently occurs at this stage (Harper 1977, Cook 1980, Roberts 1981, Cavers 1983, Chambers and MacMahon 1994). Nonetheless, the underlying factors responsible for this mortality often are unclear. In particular, few field studies have addressed the effects of pathogens on the seed bank in natural ecosystems (Chambers and MacMahon 1994, Thompson 2000, Gilbert 2002), despite a growing recognition that disease has important consequences for the ecology of many plants (Burdon 1987, Burdon and Leather 1990, Dobson and Crawley 1994, Watkinson 1998, Gilbert 2002).

The existing evidence tends to suggest that seed pathogens, particularly fungi, cause ecologically important losses in many species. For example, some studies have demonstrated that fungal pathogens can have significant impacts on seedlings in natural systems (e.g., Augspurger 1983, Packer and Clay 2000, 2003). There are a few studies that have specifically considered seeds, and these suggest that fungal pathogens may be important at this stage as well. Fungicide additions have been shown to increase seed survival in Mimosa pigra in northern Australia (Lonsdale 1993), in pioneer trees in Panama (Dalling et al. 1998), in old field plants in southern Ontario (Blaney and Kotanen 2001, 2002), and in English grassland species (Leishman et al. 2000). Still, while such studies suggest that fungi contribute to seed mortality, the pathogens involved generally remain poorly known. Studies such as Kirkpatrick and Bazzaz (1979) or Crist and Friese (1993), which both identify seed-attacking fungi and provide direct evidence of their effects on seed viability, remain rare.

One reason that such studies are difficult is that the soil community contains a tremendous diversity of fungi, including mycorrhizae, saprophytes, mycoparasites, root 
pathogens, and many other trophic types (Carroll and Wicklow 1992; Domsch et al. 1993; Dix and Webster 1995). As a result, isolating a fungus from seed-containing soil, or even from a dead seed, does not necessarily imply that it is a pathogen. As well, many fungal diseases have restricted host ranges (Burdon 1987; Agrios 1997); consequently, even a fungus demonstrated to attack a particular plant species may not act as a pathogen in combination with another, cooccurring plant. Finally, even if it causes significant mortality of a particular species at one site, a fungal pathogen may be absent or ineffective in different habitats. For example, it has been suggested that fungal pathogens generally are more prevalent in moister areas (Augspurger 1983, Augspurger and Kelly 1984); the distribution of soilborne pathogens also may be influenced by soil characteristics such as carbon content, $\mathrm{pH}$, temperature, and structure (Bruehl 1987, Dix and Webster 1995, Agrios 1997), and by the composition of the local vegetation (Bever 1994; Van der Putten and Peters 1997; Mills and Bever 1998).

In this study, we investigate the impacts of soil fungi on seeds in a range of natural environments. To accomplish this, we have compared the survival of seeds in different habitats, have isolated fungi from these seeds, and have tested the pathogenicity of isolates against two standard sets of plants. Specifically, we have addressed the following questions:

\section{1) What potential fungal pathogens colonize seeds of our study species? \\ 2) How does pathogenicity of these fungi vary among plant species? \\ 3) Does seed mortality vary among habitats?}

\section{Methods}

Study Site

The field component of this study was conducted at the University of Toronto's Joker's Hill field station, Regional Municipality of York, Ontario $\left(44^{\circ} 02^{\prime} \mathrm{N}, 79^{\circ} 31^{\prime} \mathrm{W}\right.$ : 
http://www.erin.utoronto.ca/ w3pkota/jh.html). Five locally common habitat types were chosen and six replicates of each were used (30 sites): dry meadow, wet meadow, mesic meadow, pine (Pinus resinosa) forest, and hardwood (Acer saccharum / Fagus grandifolia) forest. Meadow habitats were used as examples of sites in which the experimental plant species potentially or actually occur; forest habitats were included as examples of habitats from which the study species generally are excluded. Plant nomenclature follows Morton and Venn (1990); fungal nomenclature follows Domsch et al. (1993).

\section{Effects of habitat on seed viability}

\section{Field trial}

Mature seeds of four "focal" grasses, Bromus inermis, Danthonia spicata, Glyceria striata, and Poa pratensis, were collected from natural populations at Joker's Hill in July 1999. These grasses were chosen because they are characteristic of dry, mesic, or wet meadows in this area, and often dominate the vegetation in their preferred habitats; we selected our meadow sites in part based on the presence of the appropriate focal grasses. Bromus and Poa are typical grasses of mesic meadows. Danthonia occurs in drier meadows, while Glyceria is found in a variety of wet meadows, swamps, and marshes. Seeds of Danthonia are highly dormant, and are capable of surviving in the soil for decades (Darbyshire and Cayouette 1989). Danthonia produces both terminal and cleistogene flowers (Darbyshire and Cayouette 1989); only seeds from terminal flowers were used in our study. Poa pratensis can form long-lived seed banks (Thompson et al. 1997), and its germination is stimulated by light (Grime et al. 1988). Germination characteristics of Glyceria striata are poorly known, but related species have persistent seed banks and/or lightstimulated germination (Grime et al. 1988). Finally, some reports of the germination characteristics of Bromus inermis suggest dormancy may occur (Simpson 1990), but it still can 
germinate in either darkness or light (Baskin and Baskin 1998), as our own observations indicate. We nonetheless included it in our experiments because of its prominence in our study meadows, where it frequently is the most abundant grass, and because we wished to determine whether pathogen attack might prevent successful germination in the field.

Filled seeds of each species were identified by examination, including carefully pressing each seed; filled seeds include contents, and therefore are potentially viable, though being filled in itself does not guarantee viability. Twenty filled seeds of each species were placed between two pieces of nylon stocking held together by a plastic 35mm slide mount (Polaroid Corp., Cambridge, MA, U.S.A.). This method was used so that seeds could be suspended in close contact with the soil, while still allowing the recovery of every seed. Half of these slide mounts were treated with bleach to reduce initial fungal contaminants, in order to focus primarily on soil fungi. However, preliminary analyses revealed that surface sterilization had no significant effects on seed recovery or germinability; therefore, sterilized treatments and unsterilized treatments were pooled in all subsequent analyses.

In August 1999, assembled slide mounts were vertically inserted into the soil at each field site so that the top edge was just below the soil surface. This allowed seeds to be suspended 24cm below the soil surface - a representative depth for the soil seed bank (Leck et al. 1989, Baskin and Baskin 1998). Each of the 30 sites comprised a 4 x 4 square grid containing 16 slide mounts (4 species x 2 bleach treatments x 2 dates) spaced $1 \mathrm{~m}$ apart.

\section{Assessment of survival in the field}

In April 2000, half of the slides were recovered from each site and brought back to the lab (8 month trial); the remaining slides similarly were recovered in August 2000 (12 month trial). Each slide was opened and the seeds it contained were inspected under a dissecting microscope; this allowed the state of nearly all of the seeds (98\%) to be determined as one of the following 
conditions: germinated dead (seed with radicle emerged but shriveled), germinated alive (seed with living radicle), dead (seed soft to touch), missing (no evidence of seed), or intact (seed hard to the touch).

\section{Laboratory viability testing}

Up to 12 intact seeds from each slide mount (as available) were used to test for germinability. Seeds were placed on potting soil in cell packs and grown in a seed germinator for 10 weeks (12h: $12 \mathrm{~h} 5^{\circ} \mathrm{C}-25^{\circ} \mathrm{C}$ light-dark daily cycle; $90 \%$ humidity). As seeds germinated, seedlings were counted and removed. These methods provide a minimum estimate of viability, since living but dormant seeds may not have germinated; however, seeds of all the focal grasses exhibited high germinability. As well, any biases in germination should be distributed equally among experimental treatments; consequently, comparisons among treatments should be valid, even if absolute estimates of viability are low.

\section{Fungal survey}

Up to six of the ungerminated seeds recovered from each slide mount (as available) were used to isolate and identify fungal colonists. When possible, both dead and intact seeds were tested. Seeds were surface sterilized in $20 \%$ bleach for 60 seconds followed by three washes with sterile water. Seeds were then placed in aluminum foil, squashed with a pestle, and rinsed into a petri dish with a small amount of autoclaved distilled water. To increase the range of species detected, seeds were distributed among three different substrates (2 seeds / substrate): Martin’s rose bengal medium, V-8 medium, and bait seeds. Martin’s rose bengal and V-8 are standard agar media commonly used for soil fungi. For the third approach, roasted sesame seeds were floated in a petri dish of autoclaved distilled water, and fungi colonizing these bait seeds were observed. 


\section{Pathogenicity testing}

Since the simple presence of a fungus on or in a seed does not necessarily mean that it is a pathogen, two experiments were set up in late July 2000, using nine fungi and oomycetes chosen from those most frequently isolated during the fungal survey: Acremonium sp., Alternaria alternata, Cladosporium cladosporioides, Cochliobolus sativus, Cochliobolus geniculatus, Cylindrocarpon sp., Fusarium oxysporium, Phoma sp., and Pythium sp. All belong to genera known or suspected to include plant pathogens (Domsch et al. 1993, Farr et al. 1989). These were used to challenge both the four focal grasses and a second set of species including a broad range of old field plants.

Seeds of the four focal grasses were collected from populations at Joker's Hill in July 2000; the second set of seeds comprised 25 species (Table 1) selected from refrigerated seeds which had been collected from wild populations in southern Ontario between June 1996 and June 1998. For both trials, filled seeds were surface-sterilized with 70\% ethanol for 1 minute, 20\% bleach for 3 minutes, and 70\% ethanol for 1 minute; lab trials of similar protocols determined this method best for removing fungal contaminants while not affecting seed germination. Ten seeds per species then were placed on top of sterilized field-collected sand in a petri dish.

To inoculate the seeds, spore suspensions were made from the nine possible pathogens by scraping isolates of sporulating fungi into autoclaved distilled water and shaking vigorously. A micropipet then was used to apply $200 \mu \mathrm{L}$ of each spore suspension over the seeds in a petri dish. Autoclaved distilled water was used as a control. There were 6 replicates per treatment for the focal grasses and 3 replicates per treatment for the 25 old field species. The petri dishes were placed in the dark for two weeks to allow the fungi to colonize the seeds before germination could occur. The petris were then moved for 12 weeks to a growth chamber set at $25^{\circ} \mathrm{C}$ with a 12h:12h light-dark cycle, and were kept moist by watering regularly with autoclaved distilled 
water. Seedlings were recorded and removed as they emerged. As noted above, this procedure may underestimate viability, but should not bias comparisons among treatments. Three weeks after inoculation, the seeds were observed under a dissecting microscope and fungal colonists were identified. For the focal grasses, two of the ungerminated seeds remaining at the end of the germination period were cultured on rose bengal medium in attempt to re-isolate the inoculated fungi.

\section{Data analysis}

Results of field survival and laboratory viability testing were analyzed using split-plot factorial ANOVAs (Kirk 1982) with field site as the blocking factor; pathogenicity results were analyzed using 2-way ANOVAs. When sample sizes permitted, Tukey-Kramer tests were used for $a$ posteriori analyses as indicated in the text. Each focal grass species was analyzed separately as their germination rates and responses to treatments were expected to be intrinsically different. Type III sums of squares were used throughout. Proportions were arcsin transformed prior to analysis. Statistical analyses were performed using StatView 5.0 (SAS institute, Cary, North Carolina, USA) and SuperANOVA 1.11 (Abacus Concepts, Berkeley, California, USA.

A fungus was reported to be present if it colonized at least one experimental seed in a particular treatment, as detected either by direct observation or by any of the three culturing methods. This inclusive approach was taken because the absence of a fungus from a particular petri often may reflect chance, inviability on that medium, or competition with other fungi, rather than true absence.

\section{Results}

Effects of habitat on seed viability 
Seed viability was high for all experimental species, with either field or lab germination estimates typically ranging from 60\%-90\% (Figures 1-4). Germination of Bromus primarily occurred in the field (Figure 1), while the remaining species germinated primarily in the lab (Figures 2-4). For all species, there was a small but significant increase over time in the number of seeds recovered dead, but few habitat x season interactions (Table 2). For Glyceria and Poa, recovery of intact seeds also declined over time, though germination of recovered seeds in the lab increased (Table 2; Figures 3,4).

Recovery of each species rarely differed among habitats (Table 2). Tukey-Kramer tests indicated significantly fewer intact seeds of Bromus were recovered from mesic meadows than from deciduous forests, probably because of very high rates of germination (Figure 1).

Germination of Danthonia in the field was significantly greater in dry meadows than in pine forests, while in the lab significantly fewer seeds from dry meadows germinated than seeds from pine or deciduous forests, or mesic meadows (Figure 2). Finally, lab germination of Poa was significantly greater for seeds from pine forests than for seeds from wet meadows (Figure 4).

\section{Fungal survey}

Approximately 100 different fungi were isolated from recovered seeds (a list is available from the authors upon request). Many of these isolates were infrequent or unique. Thirty were identified at least to genus, including such familiar taxa as Aspergillus, Chaetomium, Paecilomyces, Penicillium, Rhizopus, and Trichoderma; the rest could not be positively identified due to taxonomic difficulties or lack of sporulation, but still were determined to be unique based on appearance and cultural characteristics.

All of the nine fungal species chosen for closer analysis were relatively frequent. All were isolated from each habitat type, and all occurred on multiple hosts (Table 3). Seven were isolated 
from Bromus seeds; the exceptions were Phoma sp. and Cochliobolus sativus. Similarly, seven were isolated from Glyceria; Pythium sp. and C. sativus were not. All nine fungi were found on both Danthonia and Poa, though some were rare.

These fungi differed in abundance, as well as occurrence on host species (Table 3). For example, the most abundant of these fungi was Alternaria alternata, which occurred on seeds of all four grasses and was found in $88 \%$ of samples. Other species were much less generalist in their distributions. For example, Cylindrocarpon sp. was common on Bromus, where it occurred on $50 \%$ of samples, but occurred at much lower frequency (15\%) on seeds of the other three grasses. Even more restricted were Cochliobolus sativus and Phoma. C. sativus occurred almost exclusively on Danthonia seeds, where it was present at a high frequency (91\% of samples); isolates also were obtained from two samples of Poa. Phoma sp. was most commonly found on seeds of Glyceria (43\% of samples), but also was isolated from two samples of both Danthonia and Poa.

\section{Pathogenicity testing}

\section{$\underline{\text { Focal grasses }}$}

Germination rates (Figure 5) were high overall, ranging from $82 \%$ for Bromus to $68 \%$ for Glyceria (all treatments pooled). Differences among grass species were significant $\left(\mathrm{F}_{3,200}=6.68\right.$; $\mathrm{p}<0.001)$ : Tukey-Kramer tests indicated that germination was significantly greater for Bromus than for Glyceria or Danthonia. Germination also differed among inoculation treatments $\left(\mathrm{F}_{9,200}=\right.$ 11.50; $\mathrm{p}<0.001)$. Overall, germination was highest in the controls (85\% - all species pooled) and lowest for seeds inoculated with Cochliobolus geniculatus (39\% - all species pooled). C. geniculatus, Phoma sp., and Cochliobolus sativus all produced significantly lower average germination rates than the controls (Tukey-Kramer tests). 
The effects of different fungal inoculates on germination differed among grass species (Figure 5), leading to a significant grass species $\mathrm{x}$ fungal species interaction $\left(\mathrm{F}_{27,200}=2.28\right.$; $\mathrm{p}<0.001)$. For example, though Cochliobolus geniculatus reduced germination below control values for all four grass species, Phoma sp. reduced germination below controls only for Glyceria, Poa, and Danthonia, with Glyceria experiencing the greatest reduction in germination. Similarly, inoculation with Cochliobolus sativus reduced germination below controls for these three grasses, but in this case Danthonia experienced the lowest germination. Cylindrocarpon sp. reduced germination below controls for both Poa and Glyceria, but not for Bromus or Danthonia. Finally, Pythium sp. and Acremonium sp. reduced germination below controls only for Poa.

Attempts to culture fungi from dead seeds succeeded in reisolating all inoculants, with the exception of Cladosporium sp. (Table 4). Together with its weak effects on germination (Figure 5), this result suggests that Cladosporium was functioning as a harmless commensal, rather than a true pathogen. Reisolation of the other inoculants ranged from $100 \%$ for Cochliobolus geniculatus to $16 \%$ for Cylindrocarpon sp. Phoma sp., Cochliobolus sativus, and C. geniculatus were occasionally found as contaminants, and Alternaria alternata was a very frequent contaminant, occurring on $42 \%$ of seeds to which it had not been added (Table 4).

\section{Old field species}

Germination rates differed significantly among the 25 plant species tested $\left(\mathrm{F}_{24,500}=178.62\right.$; $\mathrm{p}<0.001$ ), ranging from 94\% (Rumex crispus) to 3\% (Melilotus alba) (Figure 6). Germination also was significantly affected by the inoculation treatment applied $\left(\mathrm{F}_{9,500}=8.87 ; \mathrm{p}<0.001\right)$, but this effect varied among plant species, leading to a significant plant species $\mathrm{x}$ fungal species interaction $\left(\mathrm{F}_{216,500}=2.50 ; \mathrm{p}<0.001\right)$. For example, germination of Tragopogon dubius was reduced below control values by all fungal inoculation treatments, indicating general 
vulnerability. In contrast, Monarda fistulosa experienced high germination rates for all treatments, indicating general resistance to the fungi tested, while germination of Solidago nemoralis and Verbascum thapsus tended to be even greater in the presence of fungi than in controls. Other plants such as Daucus carota, Hieracium aurantiacum, Leonurus cardiaca, and Oenothera biennis experienced a wide range of effects ranging from high to low mortality. Finally, Asclepias syriaca, Melilotus alba, and Hypericum perforatum had low germination rates $(<20 \%)$ both for controls and for all inoculation treatments, suggesting high levels of dormancy or inviability. In some cases, higher taxonomic levels exhibited consistent responses. In particular, all five Poaceae experienced greatly reduced germination rates when inoculated with Cochliobolus geniculatus, but not the other fungi tested.

Visual inspection confirmed that all inoculates regularly occurred on the appropriate experimental seeds, ranging from $99 \%$ of inoculated seeds (Alternaria alternata) to $62 \%$ of inoculated seeds (Cylindrocarpon sp.). Contaminants also were common: only 37\% of the control treatments were free of any fungal growth whatsoever. A. alternata was the most frequent contaminant, occurring on 33\% of samples to which it had not been added. Fungal contaminants other than the nine species tested occurred in $6 \%$ of samples.

\section{Discussion}

1) What potential fungal pathogens colonize seeds of our study species?

Soil fungal communities typically are very diverse, including many species that may act as pathogens or seed-attacking saprophytes (Carroll and Wicklow 1992; Domsch et al. 1993; Dix and Webster 1995). Previous field studies have identified both generalist and specialist seed pathogens. A study using seeds of annual and perennial plants in a Wyoming shrub-steppe ecosystem found that most suspected pathogenic fungi were generalists (Crist and Friese 1993), 
while 26 of 34 fungal species isolated from seeds of annuals in early successional fields in Illinois were species-specific (Kirkpatrick and Bazzaz 1979). It is unclear whether such discrepancies indicate a difference between the systems studied, or whether they reflect biases in the identification of pathogens. Specialists often have exacting nutritional requirements, making them difficult to grow on artificial media (Garrett 1963); this may mean they are overlooked in studies not designed to detect them. Similarly, taxonomic difficulties may lead to the underestimation of specialists; for example, Pythium spp. often have been considered generalist pathogens (Walker 1969, Carlisle and Watkinson 1994), but recent studies are finding some Pythium to be host specific (Packer and Clay 2000). This suggests that some generalist Pythium "species" actually might be several co-occurring specialist strains.

Although we used "all-purpose" media, and in many cases could not determine their precise identities, we still detected a great variety of soil fungi. As well, we found that isolates varied among the four focal grasses. Many of the $>100$ isolates that we did not select for intensive analysis were isolated from only a subset of host species or habitat types, although most of these were detected in only one or a few samples; it is difficult to determine whether such isolates were host- or habitat-specific, or simply rare. Of the nine experimental fungi, two were primarily isolated from a single host: Cochliobolus sativus from Danthonia, and Phoma sp. from Glyceria. The other seven fungi occurred on all four grasses, excepting Pythium sp., which was not found on Glyceria. Some of these focal fungi also reduced the survival of the old field species tested, and all might attack plant species other than those considered in this study. However, these results still indicate that not all of these fungi were omnivorous generalists, even within a single host plant family.

In addition to host range, these fungi also differed in their frequency of occurrence, ranging from presence on $88 \%$ of samples (Alternaria alternata) to just $4 \%$ of samples (Pythium 
sp.). Such differences must be viewed with caution, since they may reflect both the media used and possible contamination of cultures by "weedy" species, notably Alternaria.

\section{2) How does pathogenicity of these fungi vary among plant species?}

Pathogenicity is a product of a pathogen's virulence and its host's susceptibility (Scheffer 1997). Plant species differ greatly in their susceptibility; for example, chestnut blight is highly lethal to American Chestnut, but has minor impacts on other co-occurring hosts (Keever 1953;

Stephenson 1986). Similarly, some related species or strains are more lethal than others; for example, Larkin et al. (1995) exposed alfalfa plants to several Pythium spp. and found they differed significantly in the intensity of their effects. However, most studies have been restricted to agricultural and/or growing plants; there have been few studies comparing the pathogenicity of diseases attacking seeds or seedlings in natural communities. Many soil fungi occurring in association with seeds may not be pathogens at all, but instead may be harmless colonists or even mutualists (Malone and Muskett 1964, Clay 1990, Clay and Schardl 2002).

In our study, at least some of the fungal species isolated did function as pathogens, as indicated by their impacts on seed survival, and this pathogenicity was dependent on the particular plant-fungus combination. For example, Cochliobolus geniculatus was isolated from all four grasses, and significantly reduced germination rates for each of these species, suggesting this fungus is a generalist pathogen with a high level of pathogenicity. Pathogenicity of other fungi apparently was more restricted. Phoma sp. induced higher mortality in seeds of the grass from which it was most frequently isolated, Glyceria striata, than in other grass species; while some Phoma are generalists, many species and subspecies are specialists of a single host (Farr et al. 1989). Cochliobolus sativus also significantly reduced germination in its most frequent host, 
Danthonia spicata, but not in the other three focal grasses. This fungus generally is considered to be nonspecialized, attacking a wide range of grasses (Garrett 1956, Domsch et al. 1993).

The four focal grasses differed in the range of fungi to which they were susceptible. Fusarium sp. and Cochliobolus geniculatus appeared to be pathogenic to Bromus, at least in the lab; in the field, rapid germination potentially may reduce the impacts of these species on seeds. Phoma sp., Alternaria alternata, Cochliobolus sativus, and C. geniculatus apparently were pathogenic to Danthonia. Phoma sp., Fusarium sp., Cylindrocarpon sp., C. sativus, Acremonium sp., and C. geniculatus damaged Glyceria. Finally, Phoma sp., Fusarium sp. A. alternata, C. sativus, Pythium sp., Acremonium sp., and C. geniculatus attacked Poa. Though it occurred naturally on all four focal grasses, Cladosporium sp. could not be re-isolated from any inoculated seeds, suggesting that it was not infecting them internally as a pathogen would be expected to do.

A great diversity of interactions also was detected between the experimental fungi and the larger set of old field plants. Some plants exhibited general resistance or vulnerability, perhaps suggesting some feature of seed structure or chemistry that inhibited all potential pathogens. For example, the high germination rate of Monarda fistulosa did not appear to be significantly affected by any of the experimental fungi; conversely, Tragopogon dubius experienced significantly lower germination with all nine fungi compared with the control. Other plants provided evidence of species-specific pathogenicity: Oenothera biennis experienced a wide range of effects from high to low seed mortality, depending on the fungus involved. Finally, there was evidence of effects specific to higher taxonomic levels. Notably, all five grasses shared similar responses to the experimental inoculants: all experienced a large decrease in germination when exposed to Cochliobolus geniculatus, but not when exposed to the other eight fungi tested. The weaker effects of these fungi relative to their impacts in trials using only the four focal grasses probably reflects the smaller sample sizes used in the old field plant trials. 


\section{3) Does seed mortality vary among habitats?}

Seed and seedling mortality often vary among habitats, in some cases as a direct result of fungal attack. For example, Augspurger (1983) and Augspurger and Kelly (1984) found seedlings of a tropical tree had an increased probability of survival in light-gaps relative to damper forest understory because of reduced impacts of damping-off fungi. Similarly, Blaney and Kotanen (2001) found that seeds of numerous upland plant species had lower rates of survival in wetland sites than upland sites, but that this difference was largely eliminated with the addition of fungicide.

In contrast with these studies, we found only limited evidence to suggest that losses of buried grass seeds may be habitat-dependent. This is surprising since previous work at this site has clearly demonstrated that seed mortality varies among habitats, largely as a result of attack by fungal pathogens (Blaney and Kotanen 2001). It may be that higher losses to fungi in some habitats were masked by other factors affecting seed performance: unlike Blaney and Kotanen (2001), we did not use fungicides to control pathogen populations, and as a result we cannot distinguish losses to pathogens from losses to other causes. Other research at the same site has found that grasses often respond rather weakly to fungicide applications in comparison with different taxa (Blaney and Kotanen 2001, 2002) perhaps implying that other sources of mortality, such as premature germination, are more important than pathogens in many instances.

Alternatively, perhaps the lack of between-habitat differences reflects the ubiquitous presence of some common pathogen. Each of the fungal species we chose for intensive analysis occurred in all five habitats despite physical and biological differences among sites, and despite evidence of restricted host range. For example, Cochliobolus sativus was isolated almost exclusively from 
seeds of Danthonia spicata, but still was detected in all habitats, not just the dry meadows where this grass typically occurs.

\section{4) Implications}

Our results show that fungal seed pathogens are common, ubiquitous, and potentially lethal: in many cases, our experimental fungi reduced germination by more than $50 \%$. As well, the effects of these pathogens depend on the combination of fungus and plant species considered, suggesting that at least some fungi may select against particular plants; for example, grasses were especially vulnerable to certain "specialist" fungi in the lab, though it is unclear if this is equally true in the field. Recruitment in natural habitats is affected by many factors other than pathogens, including dispersal, safe sites, drought, seed predators, and competition. Nonetheless, our results suggest that seed-pathogenic fungi have the potential to affect plant communities by strongly reducing the recruitment of susceptible species, and ultimately by altering their distribution and abundance.

\section{Acknowledgements}

This research was supported by NSERC Research and Equipment Grants to PMK, with additional funding from Human Resources Development Canada. Many students and volunteers contributed assistance, including Marc Johnson, Uyen Dias, Devin Tremblay, and Deborah Manners. Linda Kohn and Dave Malloch contributed invaluable advice concerning fungal techniques, and help with identification. Special thanks to Murray Koffler for his donation to the University of Toronto of the property that has become the Joker's Hill research station. This is a publication of the Koffler Scientific Reserve at Jokers Hill. 


\section{References}

Agrios G.N. 1997. Plant Pathology (fourth edition). Academic Press, London.

Augspurger C.K. 1983. Seed dispersal of the tropical tree Platypodium elegans, and the escape of its seedlings from fungal pathogens. Journal of Ecology 71:759-771.

Augspurger C.K. and Kelly C.K. 1984. Pathogen mortality of tropical tree seedlings: experimental studies of the effects of dispersal distance, seedling density, and light conditions. Oecologia 61:211-217.

Baskin C.C. and Baskin J.M. 1998. Seeds: Ecology, Biogeography, and Evolution of Dormancy and Germination. Academic Press, San Diego.

Bever J.D. 1994. Feedback between plants and their soil communities in an old field community. Ecology 75: 1965-1977.

Blaney C.S. and Kotanen P.M. 2001. Effects of fungal pathogens on seeds of native and exotic plants: a test using congeneric pairs. Journal of Applied Ecology 38:1104-1113.

Blaney C.S. and Kotanen P.M. 2002. Persistence in the seed bank: an experimental comparison of native and alien plants. Écoscience 9:509-517.

Bruehl G.W. 1987. Soilborne Plant Pathogens. MacMillan Publishing Company, New York.

Burdon J.J. 1987. Diseases and Plant Population Biology. Cambridge University Press, Cambridge.

Burdon J.J and Leather S.R. 1990. Pests, Pathogens, and Plant Communities. Blackwell Scientific Publications, Oxford.

Carlisle M.J. and Watkinson S.C 1994. The Fungi. Academic Press Harcourt Brace and Co., New York.

Carroll G.C. and Wicklow D.T. 1992. The Fungal Community: Its Organization and Role in the Ecosystem (second edition). Marcel Dekker Inc., New York. 
Cavers P.B. 1983. Seed demography. Canadian Journal of Botany 61:3578-3590.

Chambers J.C. and MacMahon J.A. 1994. A day in the life of a seed: movements and fates of seeds and their implications for natural and managed systems. Annual Review of Ecology and Systematics 25:263-292.

Clay K. 1990. Fungal endophytes of grasses. Annual Review of Ecology and Systematics 21:275297.

Clay K. and Schardl C. 2002. Evolutionary origins and ecological consequences of endophyte symbioses with grasses. The American Naturalist 160 (Supplement): S99-S127.

Cook R. 1980. The biology of seeds in soil. In: Solbrig, O.E. (ed), Demography and Evolution in Plant Populations. University of California Press, Berkeley, pp.107-129

Crist T.O. and Friese C.F. 1993. The impact of fungi on soil seeds: Implications for plants and granivores in a semiarid shrub-steppe. Ecology 74:2231-2239.

Dalling J.W., Swaine M.D. and Garwood N.C. 1998. Dispersal patterns and seed bank dynamics of pioneer trees in moist tropical forest. Ecology 79: 564-578.

Darbyshire S.J. and Cayouette J. 1989. The biology of Canadian weeds 92: Danthonia spicata (L.). Canadian Journal of Plant Science 69:1217-1233.

Dix N.J. and Webster J. 1995. Fungal Ecology. Chapman and Hall, New York.

Dobson A. and Crawley M. 1994. Pathogens and the structure of plant communities. Trends in Ecology and Evolution 9:393-398.

Domsch K.H., Gams W. and Anderson T. 1993. Compendium of Soil Fungi (2 vols.) Academic Press, London.

Farr D.F., Bills G.P., Chamuris G.P. and Rossman A.Y. 1989. Fungi on Plants and Plant Products in the United States. APS Press, Saint Paul. Garrett S.D. 1956. Biology of Root-infecting Fungi. Cambridge University Press, London. 
Garrett S.D. 1963. Soil Fungi and Soil Fertility. The MacMillan Company, New York.

Gilbert, G.S. 2002. Evolutionary ecology of plant diseases in natural ecosystems. Annual Review of Phytopathology 40, 13-43.

Grime J.P., Hodgson J.G. and Hunt R. 1988. Comparative Plant Ecology. Unwin Hyman, London.

Harper J.L. 1977. Population Biology of Plants. Academic Press, London.

Keever C. 1953. Present composition of some stands of the former oak-chestnut forest in the southern Blue Ridge Mountains. Ecology 34:44-54.

Kirk R.E. 1982. Experimental Design: Procedures for the Behavioral Sciences (second edition). Brooks and Cole, Monterey.

Kirkpatrick B.L. and Bazzaz F.A. 1979. Influence of certain fungi on seed germination and seedling survival of four colonizing annuals. Journal of Applied Ecology 16:515-527.

Larkin R.P., English J.T. and Mihail J.D. 1995. Identification, distribution and pathogenicity of Pythium spp. associated with alfalfa seedlings. Soil Biology and Biochemistry 27:357-364.

Leck M.A., Parker V.T. and Simpson R.L. 1989. Ecology of Soil Seed Banks. Academic Press, San Diego.

Leishman M.R., Masters G.J., Clarke I.P. and Brown, V.K. 2000. Seed bank dynamics: the role of fungal pathogens and climate change. Functional Ecology 14:293-299.

Lonsdale W.M. 1993. Losses from the seed bank of Mimosa pigra: Soil micro-organisms vs. temperature fluctuations. Journal of Applied Ecology 30: 654-660.

Malone J.P. and Muskett A.E. 1964. Seed-borne Fungi. The International Seed Testing Association, Wageningen.

Mills K.E. and Bever J.D. 1998. Maintenance of diversity within plant communities: soil pathogens as agents of negative feedback. Ecology 79: 1595-1601. 
Morton J.K. and Venn J.M. 1990. A Checklist of the Flora of Ontario: Vascular Plants. University of Waterloo Biology Series, Waterloo.

Packer A. and Clay K. 2000. Soil pathogens and spatial patterns of seedling mortality in a temperate tree. Nature 404:278-281.

Packer A. and Clay K. 2003. Soil pathogens and Prunus serotina seedling and sapling growth near conspecific trees. Ecology 84:108-119.

Roberts E.H. 1981. Seed banks in soils. Advances in Applied Biology 6:1-55.

Scheffer R.P. 1997. The Nature of Disease in Plants. Cambridge University Press, Cambridge.

Simpson G.M. 1990. Seed Dormancy in Grasses. Cambridge University Press, Cambridge.

Stephenson S.L. 1986. Changes in a former chestnut-dominated forest after a half century of succession. American Midland Naturalist 116:173-179.

Thompson K. 1987. Seeds and seed banks. New Phytologist 106 (Supplement): 23-34.

Thompson K. 2000. The Functional Ecology of Soil Seed Banks. In: Fenner M. (ed.), Seeds: The Ecology of Regeneration in Plant Communities (second edition). CAB International, Oxford, pp. $215-235$.

Thompson K., Bakker J.P. and Bekker R.M. 1997. Soil Seed Banks of North-West Europe: Methodology, Density and Longevity. Cambridge University Press, New York.

Van der Putten W.H. and Peters B.A.M. 1997. How soil-borne pathogens may affect plant competition. Ecology 78:1785-1795.

Walker J.C. 1969. Plant Pathology. McGraw-Hill, New York.

Watkinson A.R. 1998. The role of the soil community in plant population dynamics. Trends in Ecology and Evolution 13:171-172. 
Table 1. The 25 old field species used to examine pathogenicity of the nine experimental fungi.

\begin{tabular}{|c|c|}
\hline Species & Family \\
\hline Daucus carota & Apiaceae \\
\hline Asclepias syriaca & Asclepiadaceae \\
\hline Aster ericoides & Asteraceae \\
\hline Tragopogon dubius & Asteraceae \\
\hline Chrysanthemum leucanthemum & Asteraceae \\
\hline Hieracium aurantiacum & Asteraceae \\
\hline Solidago nemoralis & Asteraceae \\
\hline Leonurus cardiaca & Lamiaceae \\
\hline Chenopodium album & Chenopodiaceae \\
\hline Carex muhlenbergii & Cyperaceae \\
\hline Carex spicata & Сyperaceae \\
\hline Melilotus alba & Fabaceae \\
\hline Monarda fistulosa & Lamiaceae \\
\hline Oenothera biennis & Onagraceae \\
\hline Plantago major & Plantaginaceae \\
\hline Bromus inermis & Poaceae \\
\hline Danthonia spicata & Poaceae \\
\hline Poa pratensis & Poaceae \\
\hline Glyceria striata & Poaceae \\
\hline Elymus repens & Poaceae \\
\hline Rumex crispus & Polygonaceae \\
\hline Geum urbanum & Rosaceae \\
\hline Hypericum perforatum & Clusiaceae \\
\hline Potentilla recta & Rosaceae \\
\hline Verbascum thapsus & Scrophulariaceae \\
\hline
\end{tabular}


Table 2. Results of split-plot factorial ANOVAs for field-exposed seeds of the four focal grasses. "Habitat" refers to the habitat to which seeds were exposed; "season" refers to recovery date. Error degrees of freedom for all tests $=24$, except as indicated.

\begin{tabular}{|c|c|c|c|c|c|c|c|c|}
\hline \multirow[b]{2}{*}{ Factor } & \multicolumn{2}{|c|}{ Dead } & \multicolumn{2}{|c|}{ Germinated (field) } & \multicolumn{2}{|c|}{ Intact } & \multicolumn{2}{|c|}{ Germinated (lab) } \\
\hline & df & $\mathrm{F}$ & $\mathrm{df}$ & $\mathrm{F}$ & df & $\mathrm{F}$ & $\mathrm{df} \dagger$ & $\mathrm{F}$ \\
\hline \multicolumn{9}{|l|}{ Bromus inermis } \\
\hline habitat & 4 & 0.316 & 4 & 1.664 & 4 & $3.427 *$ & 2 & 0.253 \\
\hline season & 1 & $5.653 *$ & 1 & 0.129 & 1 & 3.549 & 1 & 0.493 \\
\hline habitat x season & 4 & 1.025 & 4 & 0.521 & 4 & 1.165 & 2 & 0.117 \\
\hline \multicolumn{9}{|c|}{ Danthonia spicata } \\
\hline habitat & 4 & 2.175 & 4 & $3.192 *$ & 4 & 2.184 & 4 & $3.982 *$ \\
\hline season & 1 & $12.723 * *$ & 1 & 0.918 & 1 & 3.086 & 1 & 1.534 \\
\hline habitat x season & 4 & 2.662 & 4 & 0.885 & 4 & 1.529 & 4 & $3.713^{*}$ \\
\hline \multicolumn{9}{|l|}{ Glyceria striata } \\
\hline habitat & 4 & 0.969 & 4 & 1.472 & 4 & 0.444 & 4 & 0.693 \\
\hline season & 1 & $46.212 * * *$ & 1 & 2.750 & 1 & $19.454 * * *$ & 1 & $12.331 * *$ \\
\hline habitat x season & 4 & 1.493 & 4 & 1.341 & 4 & $2.797 *$ & 4 & 1.701 \\
\hline \multicolumn{9}{|l|}{ Poa pratensis } \\
\hline habitat & 4 & 0.904 & 4 & 0.711 & 4 & 0.928 & 4 & $2.788 *$ \\
\hline season & 1 & $4.873^{*}$ & 1 & 0.095 & 1 & 4.799* & 1 & $10.110 * *$ \\
\hline habitat x season & 4 & 1.683 & 4 & 1.019 & 4 & 1.378 & 4 & 0.217 \\
\hline
\end{tabular}


Table 3. Occurrence of the experimental fungal species on seeds of focal grasses after 8 months and 12 months in the field. The habitats sampled are Dry Meadow (DM), Mesic meadow (MM), Wet Meadow (WM), Deciduous Forest (DF), and Pine Forest (PF).

Entries indicate the number of sites where each fungus was detected ( $\mathrm{n}=6$ except for DF, where $\mathrm{n}=5$ plots were recovered). Only nonzero entries are shown.

\begin{tabular}{|c|c|c|c|c|c|c|c|c|c|c|c|c|c|c|c|c|c|c|c|c|c|}
\hline \multirow[t]{2}{*}{ Fungus } & \multirow[t]{2}{*}{ Sampling } & \multicolumn{5}{|c|}{ Bromus inermis } & \multicolumn{5}{|c|}{ Danthonia spicata } & \multicolumn{5}{|c|}{ Glyceria striata } & \multicolumn{5}{|c|}{ Poa pratensis } \\
\hline & & $\mathrm{DM}$ & $\mathrm{MM}$ & WM & DF & $\mathrm{PF}$ & $\mathrm{DM}$ & $\mathrm{MM}$ & WM & $\mathrm{DF}$ & $\mathrm{PF}$ & $\mathrm{DM}$ & $\mathrm{MM}$ & WM & DF & $\mathrm{PF}$ & $\mathrm{DM}$ & $\mathrm{MM}$ & WM & $\mathrm{DF}$ & $\mathrm{PF}$ \\
\hline Acremonium & 8 months & & & & 1 & & 1 & & & & & & 1 & & 1 & & & & 1 & & \\
\hline sp. & 12 months & 1 & & 1 & & 1 & 1 & 2 & 1 & 1 & 1 & & & & 1 & 2 & 3 & 1 & & & 1 \\
\hline Alternaria & 8 months & 5 & 5 & 6 & 5 & 6 & 5 & 5 & 6 & 5 & 6 & 6 & 6 & 6 & 5 & 6 & 6 & 4 & 6 & 5 & 6 \\
\hline alternata & 12 months & 3 & 4 & 6 & 4 & 4 & 4 & 4 & 4 & 5 & 6 & 4 & 5 & 4 & 5 & 5 & 5 & 4 & 6 & 5 & 6 \\
\hline Cladosporium & 8 months & & 4 & & 2 & 1 & 1 & & 1 & & 1 & & 1 & 1 & 1 & 1 & 2 & 2 & & 1 & 1 \\
\hline cladosporioides & 12 months & 1 & 3 & & 3 & 2 & 1 & 1 & & 2 & 3 & 1 & 1 & 1 & & 1 & 1 & 3 & 2 & 3 & 4 \\
\hline Cochliobolus & 8 months & & & & & & 1 & & & & & 1 & & & & & & & & & \\
\hline geniculatus & 12 months & 1 & 1 & 3 & 1 & & & 2 & 1 & & 2 & & & 1 & & & & & 1 & 1 & \\
\hline Cochliobolus & 8 months & & & & & & 6 & 5 & 6 & 5 & 6 & & & & & & & 1 & 1 & & \\
\hline sativus & 12 months & & & & & & 5 & 6 & 4 & 5 & 5 & & & & & & & & & & \\
\hline Cylindrocarpon & 8 months & 2 & 2 & 2 & 1 & 6 & 1 & 2 & & 2 & 4 & 1 & 1 & & & 1 & & 2 & 1 & & 1 \\
\hline sp. & 12 months & 3 & 3 & 4 & 3 & 3 & 2 & & 1 & 1 & & & 1 & 1 & & 2 & 1 & & & & 1 \\
\hline Fusarium & 8 months & 2 & 1 & 1 & & 1 & & 1 & & & 1 & 1 & & & & 1 & 1 & 1 & & & \\
\hline oxysporium & 12 months & & & & & & & & & & & & & & & & & & & 1 & \\
\hline Phoma & 8 months & & & & & & & & & & & 1 & 3 & 3 & 1 & 3 & & & & & \\
\hline sp. & 12 months & & & & & & 1 & 1 & & & & 2 & 3 & 2 & 3 & 4 & & & 1 & 1 & \\
\hline
\end{tabular}




\begin{tabular}{|c|c|c|c|c|c|c|c|c|c|c|}
\hline Pythium & 8 months & 1 & 1 & 2 & 1 & 1 & 1 & 1 & 1 & 1 \\
\hline sp. & 12 months & & & & & & & & & \\
\hline
\end{tabular}


Table 4. Re-isolation of the nine experimental fungi from the four focal grasses. "I" represents the percentage of nongerminating seeds from which the fungal inoculant was reisolated. "C" refers to the percentage of seeds for which the fungus was a known contaminant (i.e., was recovered from seeds not originally inoculated with this species). Total sample size $=173$ trials.

\begin{tabular}{|c|c|c|c|c|c|c|c|c|c|c|}
\hline & \multicolumn{2}{|c|}{$\begin{array}{l}\text { Acremonium } \\
\text { sp. }\end{array}$} & \multicolumn{2}{|c|}{$\begin{array}{l}\text { Alternaria } \\
\text { sp. }\end{array}$} & \multicolumn{2}{|c|}{$\begin{array}{l}\text { Cladosporium } \\
\text { cladosporioides }\end{array}$} & \multicolumn{2}{|c|}{$\begin{array}{l}\text { Cochliobolus } \\
\text { geniculatus }\end{array}$} & \multicolumn{2}{|c|}{$\begin{array}{l}\text { Cochliobolus } \\
\text { sativus }\end{array}$} \\
\hline & I & $\mathrm{C}$ & I & $\mathrm{C}$ & $\mathrm{I}$ & $\mathrm{C}$ & $\mathrm{I}$ & $\mathrm{C}$ & I & $\mathrm{C}$ \\
\hline Bromus inermis & 100 & 0 & 50 & 45 & 0 & 0 & 100 & 2 & 0 & 0 \\
\hline Danthonia spicata & 100 & 0 & 100 & 48 & 0 & 0 & 100 & 0 & 100 & 11 \\
\hline Glyceria striata & 75 & 0 & $*$ & 26 & 0 & 0 & 100 & 0 & 80 & 0 \\
\hline \multirow[t]{3}{*}{ Poa pratensis } & 100 & 0 & 100 & 50 & 0 & 0 & 100 & 0 & 60 & 0 \\
\hline & \multicolumn{2}{|c|}{$\begin{array}{l}\text { Cylindrocarpon } \\
\text { sp. }\end{array}$} & \multicolumn{2}{|c|}{$\begin{array}{l}\text { Fusarium } \\
\text { oxysporium }\end{array}$} & \multicolumn{2}{|c|}{$\begin{array}{l}\text { Phoma } \\
\text { sp. }\end{array}$} & \multicolumn{2}{|c|}{$\begin{array}{l}\text { Pythium } \\
\text { sp. }\end{array}$} & & \\
\hline & I & $\mathrm{C}$ & I & $\mathrm{C}$ & I & C & I & $\mathrm{C}$ & & \\
\hline Bromus inermis & 20 & 0 & 100 & 0 & 17 & 0 & 80 & 0 & & \\
\hline Danthonia spicata & 25 & 0 & 100 & 0 & 67 & 0 & 100 & 0 & & \\
\hline Glyceria striata & 20 & 0 & 100 & 0 & 60 & 5 & $*$ & 0 & & \\
\hline Poa pratensis & 0 & 0 & 75 & 0 & 40 & 0 & 75 & 0 & & \\
\hline
\end{tabular}




\section{Figure legends}

Figure 1. Fates of seeds of Bromus inermis exposed to different habitats for 8 and 12 months. Bars indicate the mean proportion (+ SE) of recovered seeds found dead, germinating in the field, or found intact, and the proportion of intact seeds germinating in the lab. No seeds were available for germination in the lab from the 12 month trial in dry meadows. See Table 2 for results of statistical tests.

Figure 2. Fates of seeds of Danthonia spicata exposed to different habitats for 8 and 12 months. Bars indicate the mean proportion (+ SE) of recovered seeds found dead, germinating in the field, or found intact, and the proportion of intact seeds germinating in the lab. See Table 2 for results of statistical tests.

Figure 3. Fates of seeds of Glyceria striata exposed to different habitats for 8 and 12 months. Bars indicate the mean proportion (+ SE) of recovered seeds found dead, germinating in the field, or found intact, and the proportion of intact seeds germinating in the lab. See Table 2 for results of statistical tests.

Figure 4. Fates of seeds of Poa pratensis exposed to different habitats for 8 and 12 months. Bars indicate the mean proportion (+ SE) of recovered seeds found dead, germinating in the field, or found intact, and the proportion of intact seeds germinating in the lab. See Table 2 for results of statistical tests. 
Figure 5. Interaction diagrams illustrating the mean proportion of seeds of four focal grass species germinating after exposure to nine experimental fungi (dotted lines), and an uninoculated control (solid line). Error bars are omitted for clarity, but analyses of variance detected significant differences between plant species, fungal species, and a significant plant $\mathrm{x}$ fungus interaction ( $\mathrm{p}<0.001$; see text). See Table 3 for full names of fungi.

Figure 6. Interaction diagrams illustrating the mean proportion of seeds of twenty-five old field species germinating after exposure to nine experimental fungi (dotted lines), and an uninoculated control (solid line). Error bars are omitted for clarity, but analyses of variance detected significant differences between plant species, fungal species, and a significant plant $\mathrm{x}$ fungus interaction ( $\mathrm{p}<0.001$; see text). See Table 1 for full names of experimental plant species; see Table 3 for full names of fungi. 

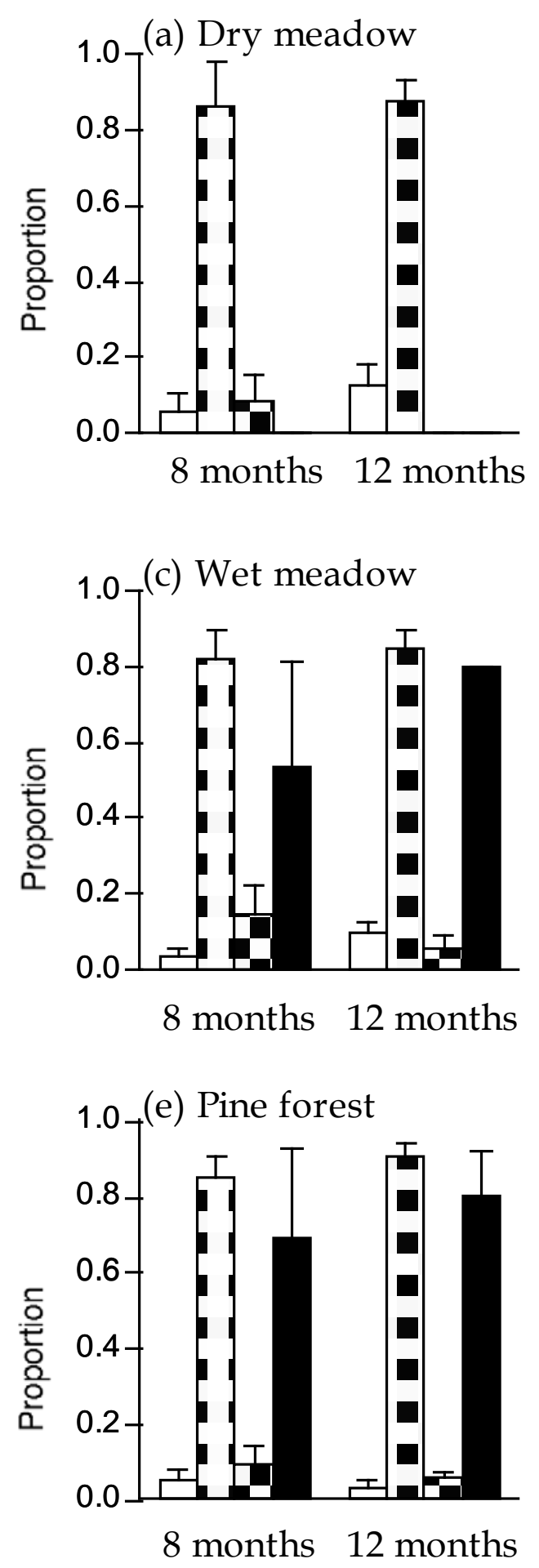
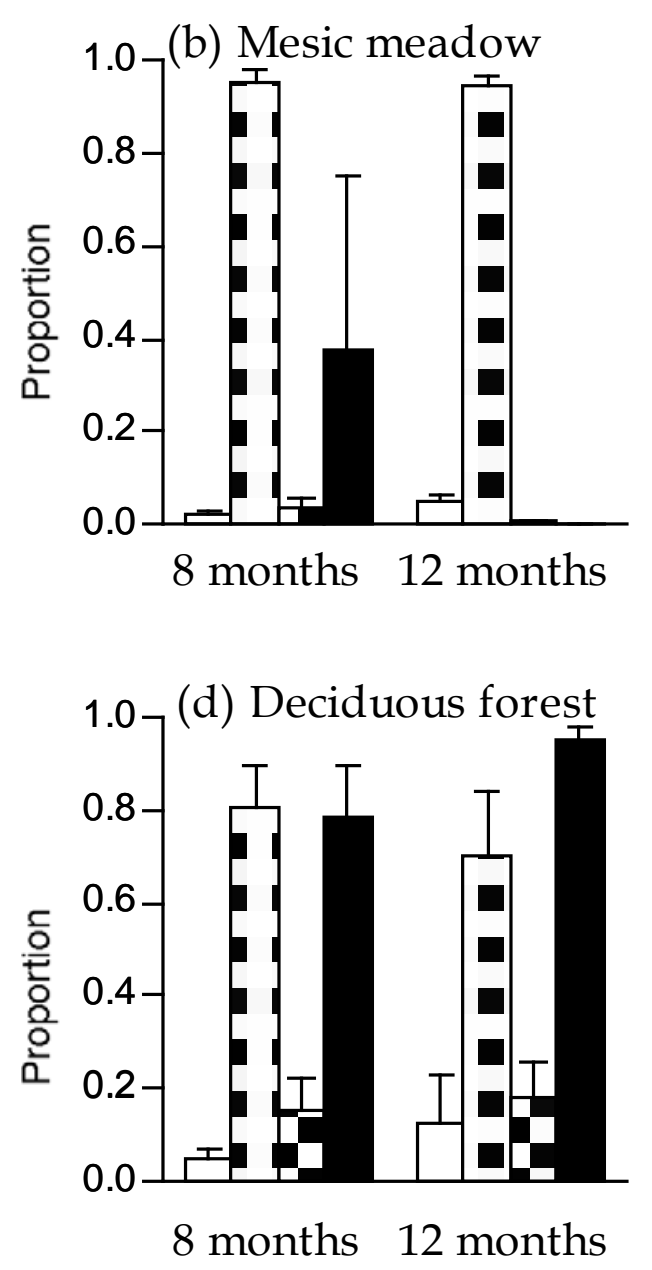

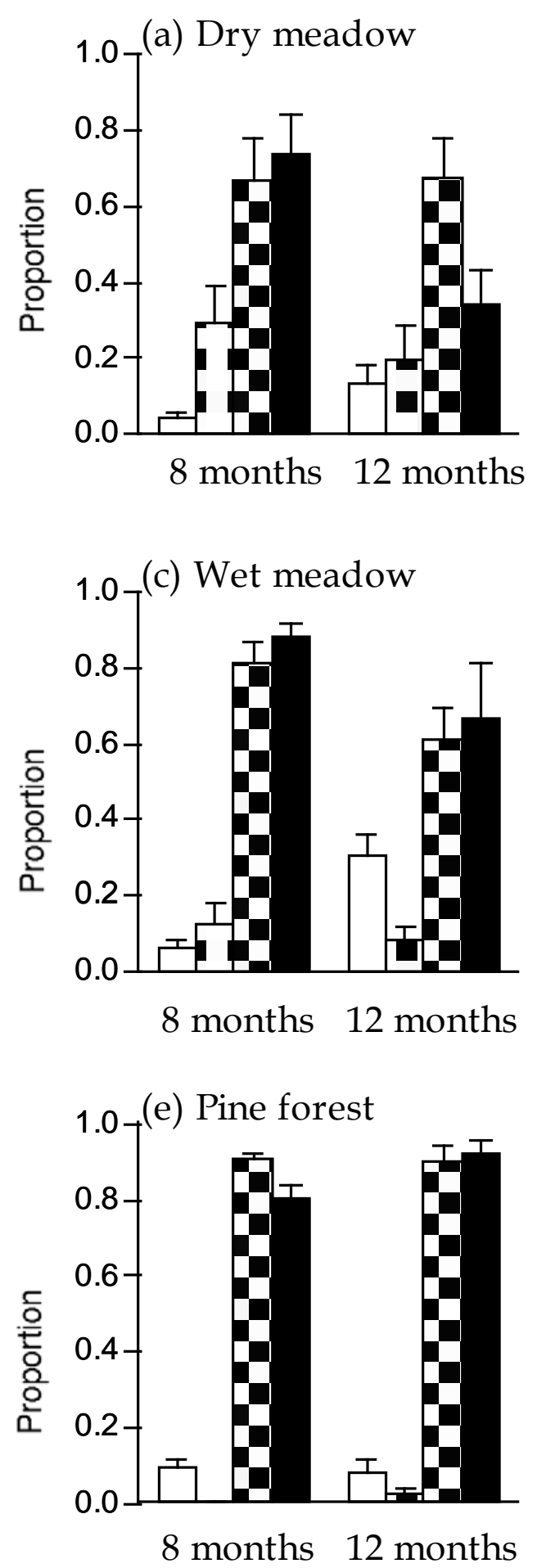
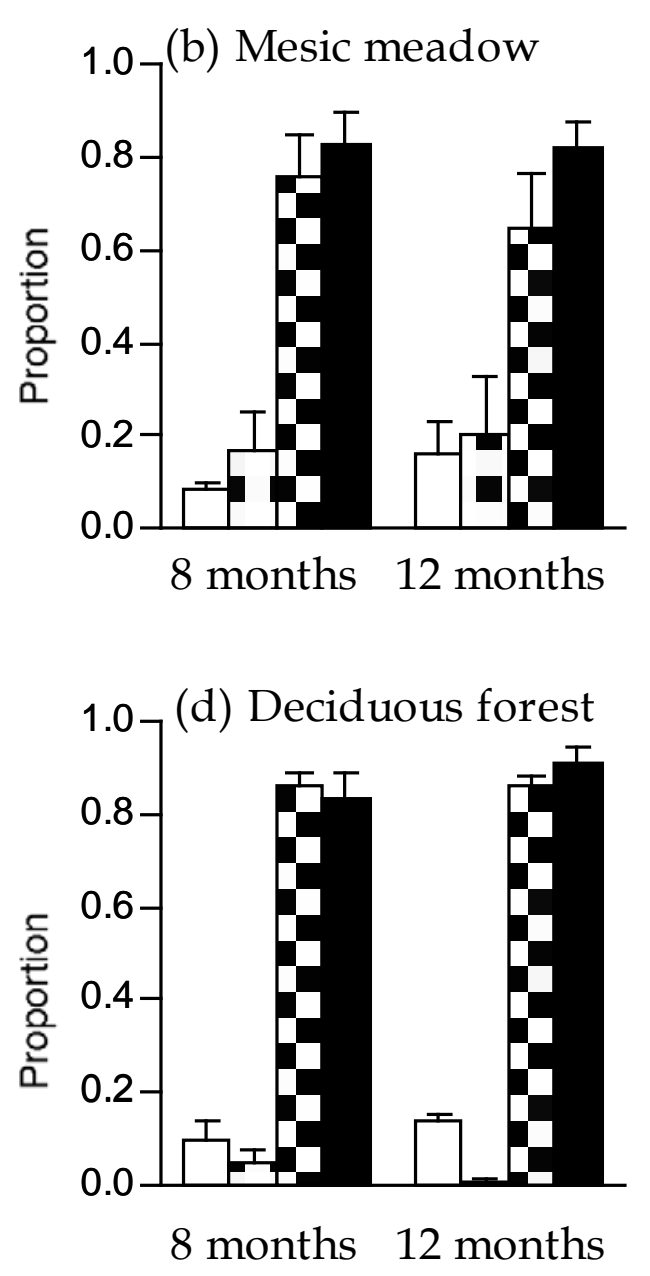

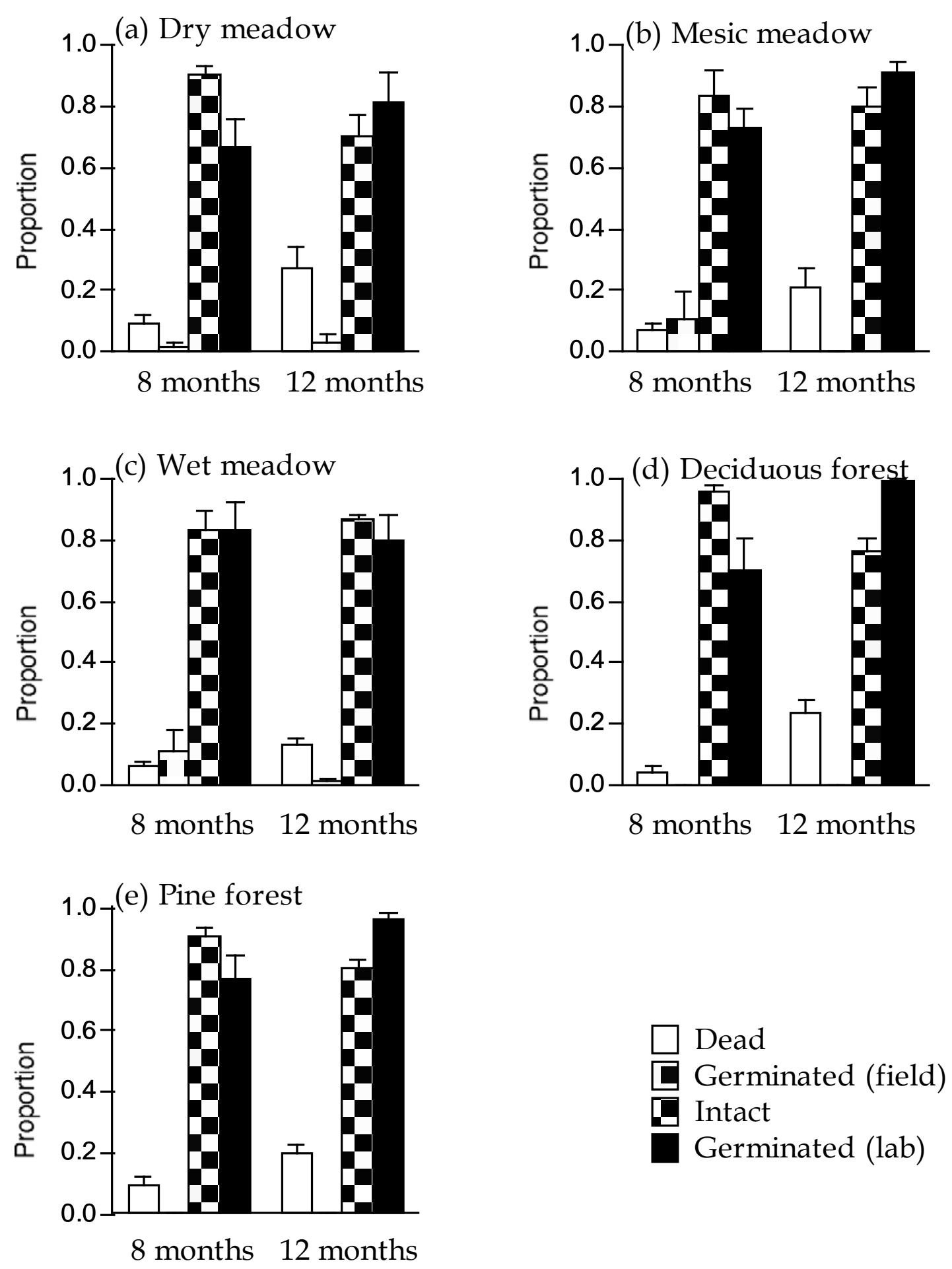

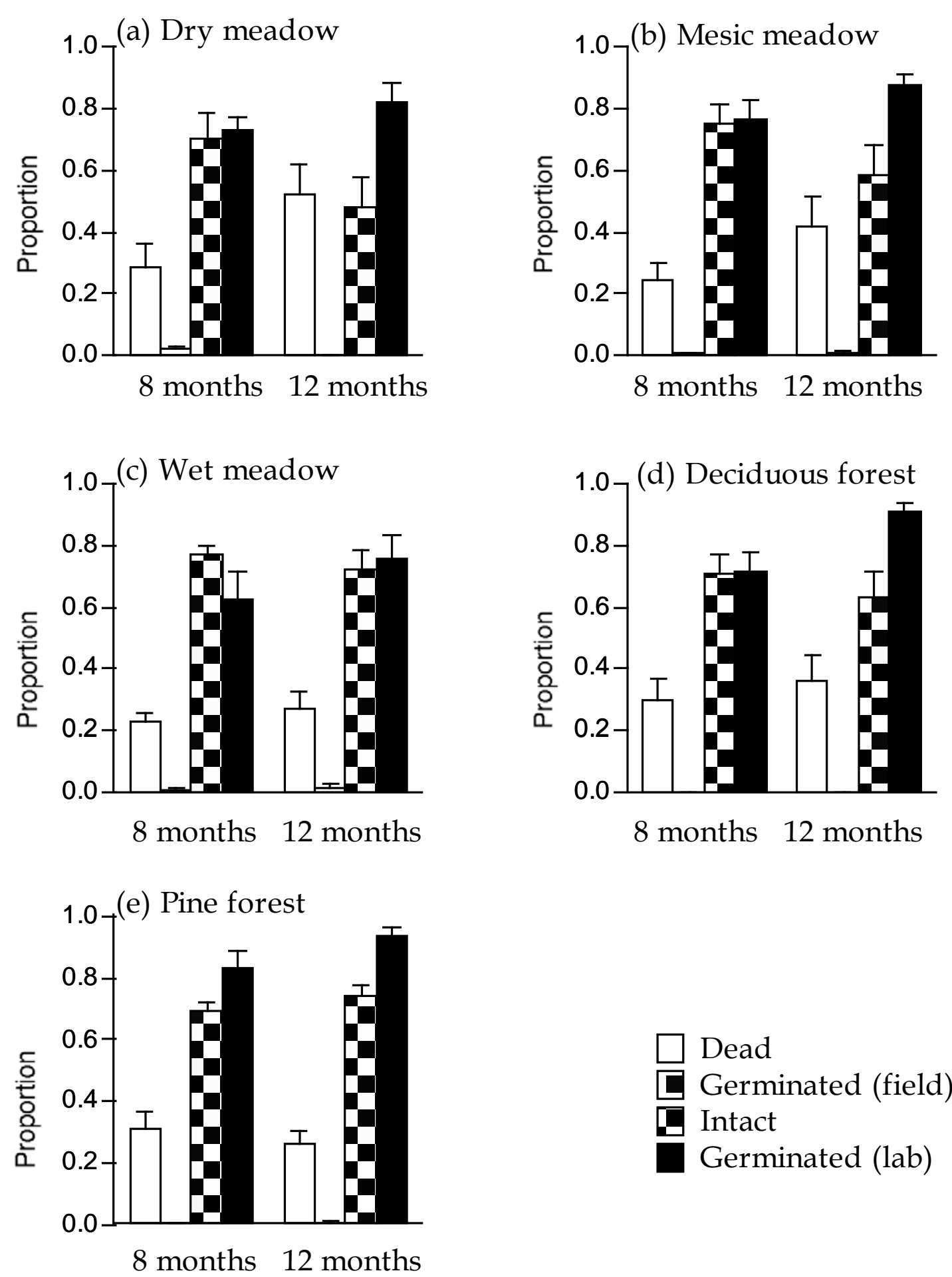

$\square$ Dead

$\square$ Germinated (field)

Intact

Germinated (lab) 

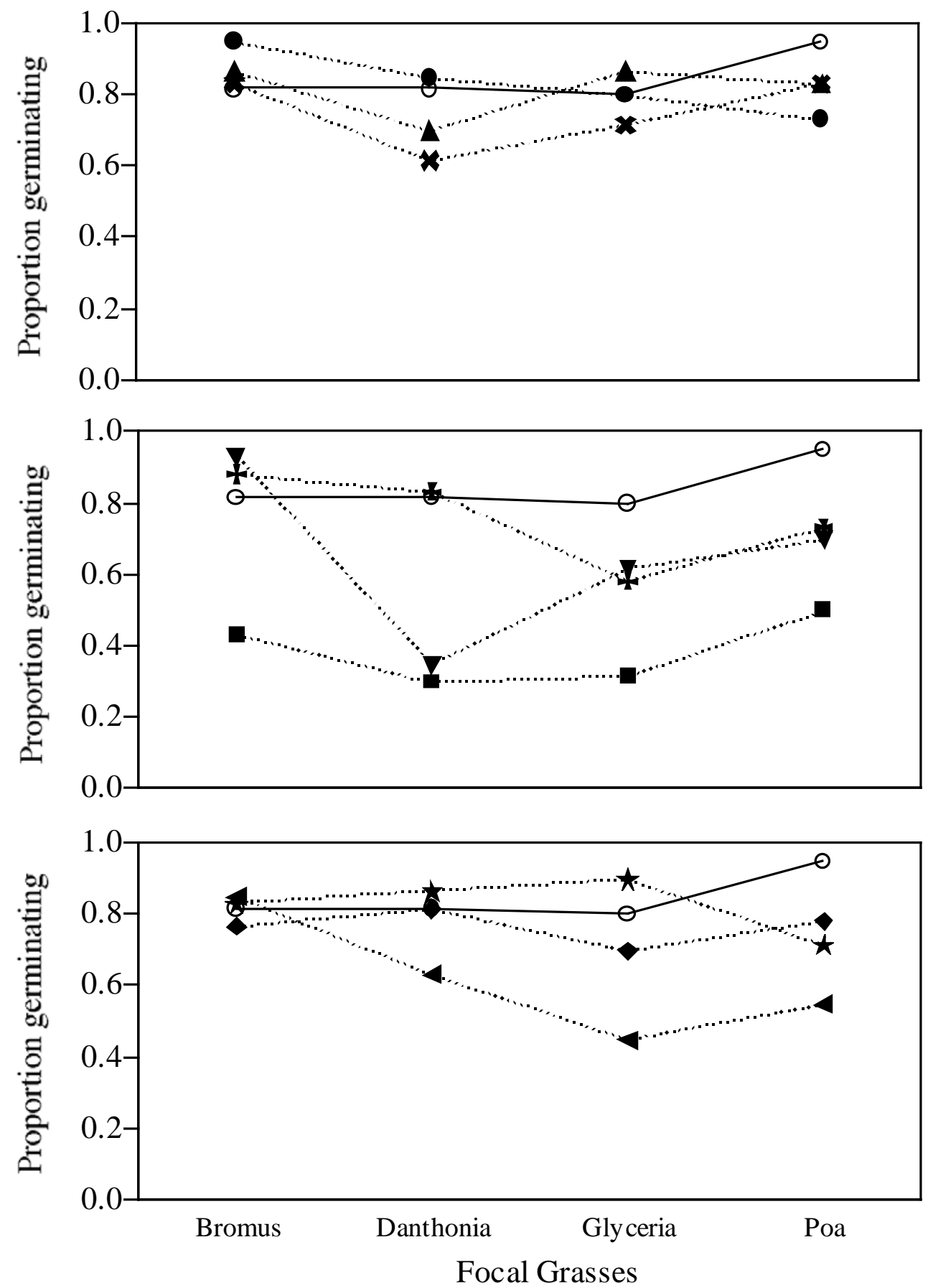

Experimental Fungi

Acremonium: J Cochliobolus geniculatus: B Fusarium: $\mathrm{F}$ Alternaria: $\mathrm{H} \quad$ Cochliobolus sativus: $\mathrm{P}$ Cladosporium: $1 \quad$ Cylindrocarpon: 5 Phoma: Q Cylindrocarpon: $5 \quad$ Pythium: 3 Uninoculated control: E 

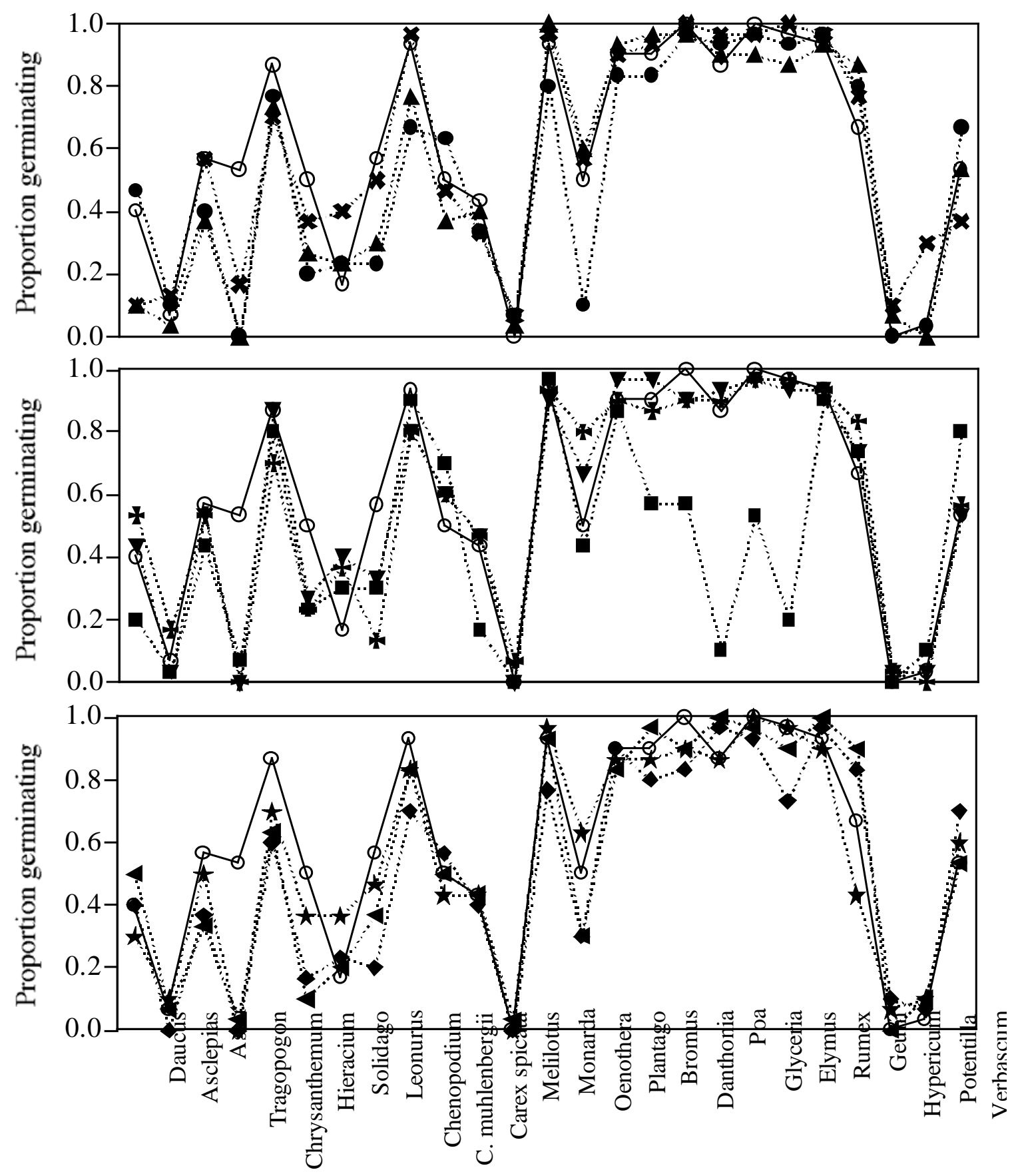

Old Field Plants

Experimental Fungi

Acremonium: J Cochliobolus geniculatus: $\mathrm{B} \quad$ Fusarium: $\mathrm{F}$ Alternaria: $\mathrm{H} \quad$ Cochliobolus sativus: $\mathrm{P}$ Phoma: $\mathrm{Q}$ Cladosporium: 1 Cylindrocarpon: 5 Pythium: 3 Uninoculated control: E 